\title{
Crypthophilic Acids A, B, and C: Resin Glycosides from Aerial Parts of Scrophularia crypthophila ${ }^{\perp}$
}

\author{
İhsan Çalış, Yükselen Sezgin, ${ }^{\dagger}$ Ali A. Dönmez, ${ }^{\#}$ Peter Rüedi, ${ }^{\S}$ and Deniz Tasdemir ${ }^{\S}$, \\ Department of Pharmacognosy, Faculty of Pharmacy, Hacettepe University, TR-06100 Ankara, Turkey, Department of Biology, Faculty of \\ Science, Hacettepe University, TR-06532 Ankara, Turkey, Institute of Organic Chemistry, University of Zurich, Winterthurerstrasse 190, \\ CH-8057 Zürich, Switzerland, Centre for Pharmacy and Phytotherapy, School of Pharmacy, University of London, 29-39 Brunswick Square, \\ London WC1N 1AX, United Kingdom
}

Received October 16, 2006

The water-soluble part of the methanolic extract from the aerial parts of Scrophularia crypthophila, through chromatographic methods, yielded three new resin glycosides, crypthophilic acids $\mathrm{A}-\mathrm{C}(\mathbf{1}-\mathbf{3})$. Compounds $\mathbf{1}-\mathbf{3}$ are tetraglycosides of $(+)-3 S, 12 S$-dihydroxypalmitic acid. The structures of these and 10 known compounds were elucidated by spectroscopic and chemical means. All natural resin glycosides known so far have been obtained from Convolvulaceae plants; this is the first report of such glycosides from another, taxonomically unrelated family (Scrophulariaceae).

In the flora of Turkey, the genus Scrophularia is represented by 59 species, 23 of which are endemic. ${ }^{1}$ Some Scrophularia species, especially $S$. nodosa, are used in folk medicine as a diuretic and for the treatment of wounds and hemorrhoids. Previous studies performed on Scrophularia species resulted in the isolation of iridoids, phenylethanoid glycosides and triterpene saponins. ${ }^{2-8}$ Here, we report the isolation and structural elucidation of three new resin glycosides, $\mathbf{1 - 3}$, and 10 known compounds. Resin glycosides $\mathbf{1 - 3}$ are being reported for the first time from a family (Scrophulariaceae) other than Convolvulaceae.

\section{Results and Discussion}

Chromatographic studies performed on the above-ground parts of Scrophularia cryptophila Boiss. \& Heldr. (Scrophulariaceae) afforded three new resin glycosides, crypthophilic acids A (1), B (2), and $\mathrm{C}(3)$. The known compounds catalpol, ${ }^{9}$ aucubin, ${ }^{10}$ methylcatalpol,,${ }^{5,8}$ harpagide, ${ }^{11}$ acetylharpagide,,${ }^{11}$ chlorogenic acid, ${ }^{12}$ tryptophan, ${ }^{13}$ acteoside (=verbascoside), ${ }^{14}$ angoroside $\mathrm{C},{ }^{3}$ and buddlejasaponin III $^{15}$ were also isolated. The structures of the known compounds were based on their spectroscopic data (UV, IR, ${ }^{1} \mathrm{H}$ NMR, ${ }^{13} \mathrm{C}$ NMR, and MS).

Compound 1 was isolated as a colorless, amorphous powder. The IR spectrum showed absorption bands for $\mathrm{OH}\left(3415 \mathrm{~cm}^{-1}\right)$, $\mathrm{CH}\left(2920 \mathrm{~cm}^{-1}\right)$, and $\mathrm{C}-\mathrm{O}-\mathrm{C}\left(1137 \mathrm{~cm}^{-1}\right)$. The negative and positive ESIMS showed quasi molecular ion peaks at $\mathrm{m} / \mathrm{z}, 903[\mathrm{M}$ $-\mathrm{H}]^{-}$and $927[\mathrm{M}+\mathrm{Na}]^{+}$, respectively, indicating a molecular formula of $\mathrm{C}_{40} \mathrm{H}_{72} \mathrm{O}_{22}$. This formula was further supported by NMR data and HRMALDIFTMS $\left(\mathrm{m} / \mathrm{z}\right.$ 927.4405 [M + Na] ${ }^{+}$; 927.4408 calcd for $\mathrm{C}_{40} \mathrm{H}_{72} \mathrm{O}_{22} \mathrm{Na}^{+}$). In the ${ }^{1} \mathrm{H}$ NMR spectrum of $\mathbf{1}$, all proton resonances were observed between $\delta 5.30$ and 3.00 and between $\delta$ 2.50 and 0.90 (Table 1). COSY experiments revealed the presence of five spin systems. Four of these were attributed to two hexose and two 6-deoxyhexose (methylpentose) units, and four anomeric protons were observed at $\delta_{\mathrm{H}} 5.21(\mathrm{~d}, J=1.7 \mathrm{~Hz}), 4.71(\mathrm{~d}, J=1.7$ $\mathrm{Hz}), 4.91(\mathrm{~d}, J=7.7 \mathrm{~Hz})$, and $4.33(\mathrm{~d}, J=7.4 \mathrm{~Hz})$. These indicated the presence of a tetraglycosidic structure. The ${ }^{13} \mathrm{C}$ NMR spectrum showed 40 carbon resonances, of which 24 were assigned to the tetraglycosidic moiety. An HSQC experiment made clear the

* Corresponding author. Tel: +90 312 3051509. Fax: +90 3123114777.

E-mail: icalis@hacettepe.edu.tr.

$\perp$ In memorium of Prof. Dr. Szabolcs Nyiredy (1950-2006).

¿ Department of Pharmacognosy, Hacettepe University.

\# Department of Biology, Hacettepe University.

$\S$ University of Zurich.

$\doteqdot$ University of London.
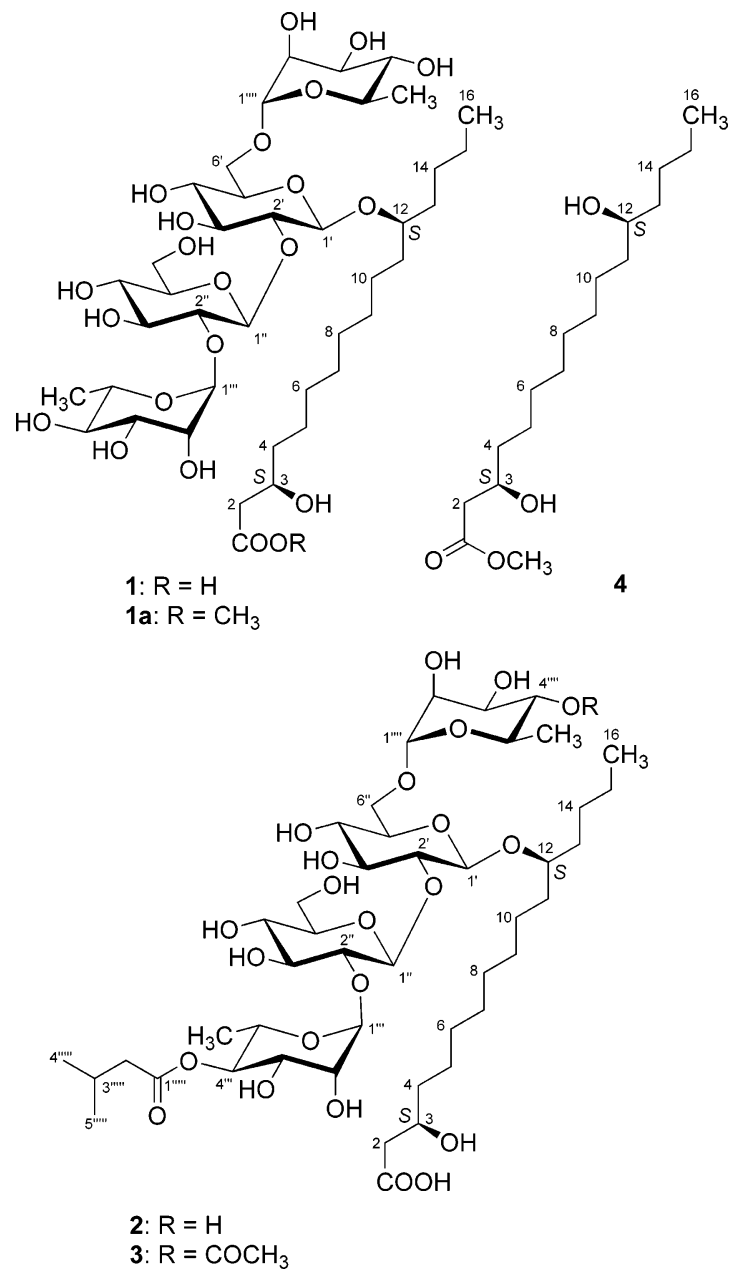

assignments of each carbon resonance involved in the five spin systems. The coupling constants of the protons and the corresponding carbon resonances together with two secondary methyl signals at $\delta_{\mathrm{H}} 1.25$ and 1.27 (each $\mathrm{d}, J=6.3 \mathrm{~Hz}$ ) indicated that 1 was a tetraglycoside composed of two glucose and two rhamnose moieties. The anomeric configurations were assigned as $\beta$ for the glucopyranosyl and $\alpha$ for the rhamnopyranosyl groups from their coupling constants (Table 1). The sugar sequence was determined on the basis of both 1D- and 2D-NMR, particularly HMBC and ROESY experiments. The chemical shift values for the carbon resonances 
Table 1. ${ }^{1} \mathrm{H}$ NMR Data of Compounds $\mathbf{1}-\mathbf{3}(600 \mathrm{MHz})^{a}$

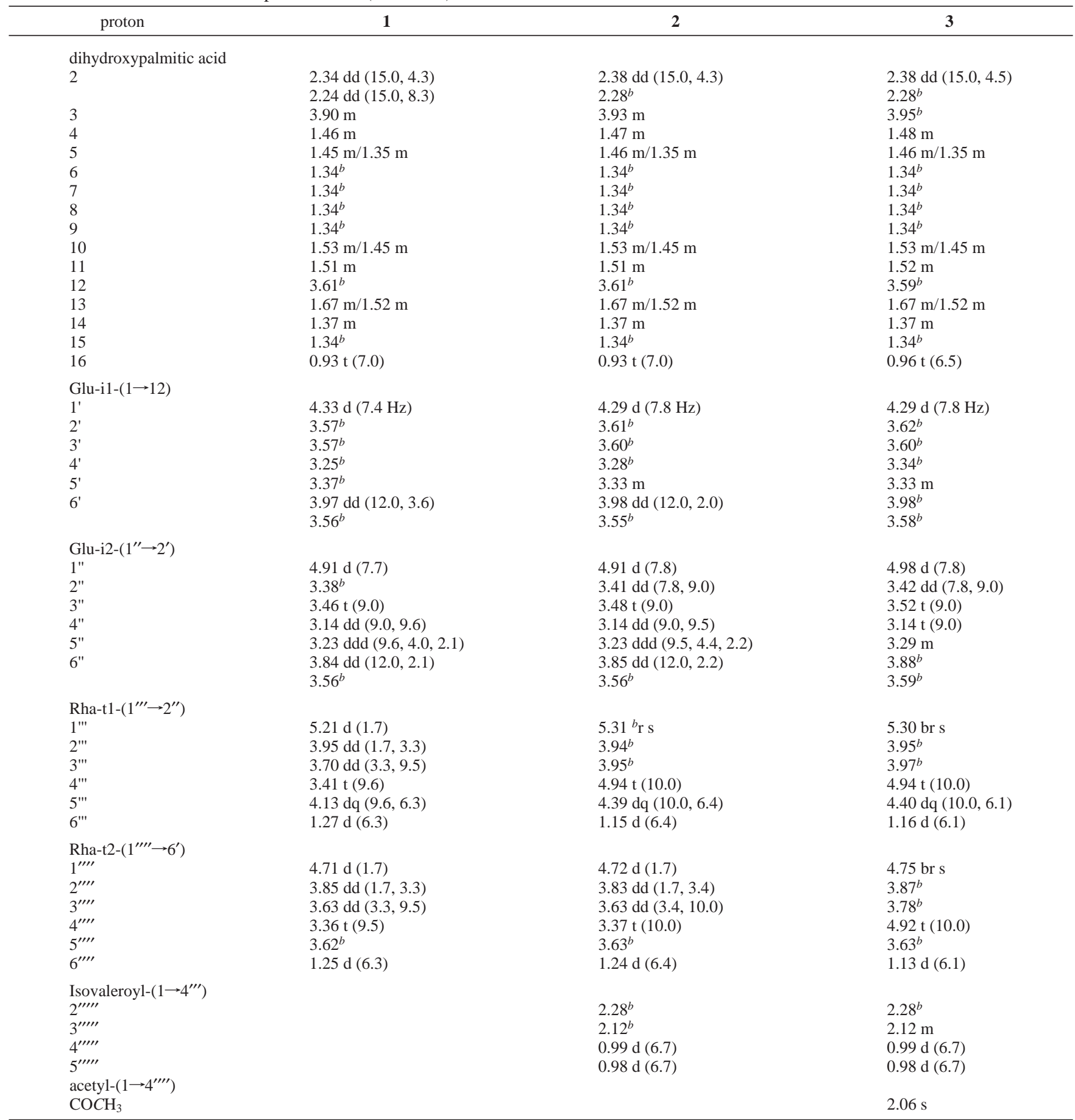

${ }^{a}$ Data recorded in $\mathrm{CD}_{3} \mathrm{OD}$. Chemical shifts $(\delta)$ are in $\mathrm{ppm}$. The spectra were referenced against the respective residual nondeuterated solvent peak $\left(\delta_{\mathrm{H}} 3.31\right)$. All assignments are based on COSY, HMQC, and HMBC experiments. ${ }^{b}$ Signal pattern unclear due to overlapping.

assigned to the rhamnose units (Rha-t1 and Rha-t2) were consistent for their being at the terminal positions of the oligosaccharide moiety. However, both C-2 resonances (C-2' and C-2"'; $\delta_{\mathrm{C}} 78.7$ and 79.6, respectively) and one of the hydroxymethylene resonances $\left(\mathrm{C}-6^{\prime} ; \delta_{\mathrm{C}} 68.4\right)$ of two glucose units were shifted downfield by +6 and +8 ppm, due to glycosidations. These observations supported the presence of a tetraglycosidic oligosaccharide structure having two inner glucose units (Glu-i1 and Glu-i2) with a rhamnose moiety at each end. In the HMBC experiment, ${ }^{1} \mathrm{H},{ }^{13} \mathrm{C}$ long-range correlations were observed between Glu-i1-C6' $\left(\delta_{\mathrm{C}} 68.4\right)$ and the anomeric proton of one of the terminal rhamnose units $(\delta 4.71$, Rha-t2-H$\left.1^{\prime \prime \prime \prime}\right)$, as well as between Glu-i1-C-2' $\left(\delta_{\mathrm{C}} 78.7\right)$ and Glu-i2-H-1" $\left(\delta_{\mathrm{H}}\right.$ 4.91). An additional ${ }^{3} J$ long-range correlation was noted between Rha-t1-H-1"' $\left(\delta_{\mathrm{H}}\right.$ 5.21) and Glu-i2-C2" $\left(\delta_{\mathrm{C}} 79.6,\right)$, and vice versa between Glu-i2-H-2" $\left(\delta_{\mathrm{H}} 3.38\right)$ and Rha-t1-C-1"' $\left(\delta_{\mathrm{C}}\right.$ 102.3). Finally, a ROESY experiment confirmed all interglycosidic linkages showing correlations between $\mathrm{H}-1^{\prime \prime \prime} / \mathrm{H}-2^{\prime \prime}, \mathrm{H}-1^{\prime \prime} / \mathrm{H}-2^{\prime}$, and $\mathrm{H}-1^{\prime \prime \prime \prime} / \mathrm{H}_{2}-6^{\prime}$. On the other hand, the anomeric $\mathrm{H}-1^{\prime}$ of the inner glucose (Glu-i1-H-1', $\left.\delta_{\mathrm{H}} 4.33\right)$ unit had strong cross-couplings with the oxymethine carbon and proton $\left(\delta_{\mathrm{C}} 84.0 ; \delta_{\mathrm{H}} 3.61\right.$, respectively) of the aglycone (see the discussion below) on both HMBC and ROESY spectra, respectively. Consequently, the sequence of the tetraglycosidic carbohydrate portion was established as $O-\alpha-$ rhamnopyranosyl- $(1 \rightarrow 2)$ - $O$ - $\beta$-glucopyranosyl- $(1 \rightarrow 2)-O$ - $[\alpha$-rhamnopyranosyl-( $1 \rightarrow 6)]-O$ - $\beta$-glucopyranose.

The remaining 16 carbon and the corresponding proton resonances belonged to the same (fifth) spin system. This spin system included signals for a carbonyl $\left(\delta_{\mathrm{C}} 181.2\right)$, a terminal methyl $\left(\delta_{\mathrm{H}}\right.$ 
$0.93,3 \mathrm{H}, \mathrm{t}, J=7.0 \mathrm{~Hz})$, and two complex oxymethine signals $\left(\delta_{\mathrm{H}}\right.$ 3.90 and 3.61), and two pairs of nonequivalent methylene protons appeared at $\delta_{\mathrm{H}} 1.52 / 1.67(\mathrm{~m})$ and 2.24/2.34 (each 1H, dd, $J=15.0$ and $4.3 \mathrm{~Hz})$. The latter pair was assigned to the protons at $\mathrm{C}-2(\delta$ $45.5 \mathrm{t}$ ), next to the carbonyl group (C-1), whereas the former pair was due to the protons at $\mathrm{C}-13(\delta 35.8)$, next to the oxygenated $\mathrm{C}-12$. There were also highly overlapped $\mathrm{CH}_{2}$ signals $\left(\delta_{\mathrm{H}} 1.34-\right.$ $1.53, \mathrm{~m})$ that were assigned to $10 \mathrm{CH}_{2}$ resonances emerging between $\delta_{\mathrm{C}} 24.0$ and 38.2 by HMQC. Altogether, these signals were ascribable to a dihydroxyhexadecanoic acid (=dihydroxypalmitic acid) aglycone unit. The positions of the $\mathrm{OH}$ groups and the site of glycosidation were determined by chemical and spectroscopic means. Methylation of $\mathbf{1}$ with diazomethane yielded a single methyl ester (1a), which contained a carboxymethyl signal at $\delta_{\mathrm{H}} 3.67$ in its ${ }^{1} \mathrm{H}$ NMR spectrum. Moreover, the negative and positive ions ESIMS of 1a showed quasi molecular ion peaks at $\mathrm{m} / \mathrm{z} 917$ [M $\mathrm{H}]^{-}$and $941[\mathrm{M}+\mathrm{H}]^{+}$, respectively $\left(\mathrm{C}_{41} \mathrm{H}_{74} \mathrm{O}_{22}\right)$. This clearly implied that the carboxyl function of the dihydroxypalmitic acid was free and that one of the $\mathrm{OH}$ groups of the dihydroxypalmitic acid was glycosidated. The oxymethine proton at $\delta_{\mathrm{H}} 3.90(\mathrm{H}-3)$ showed scalar coupling with $\mathrm{H}-4(\delta 1.46, \mathrm{~m})$ and $\mathrm{H}_{2}-2$ in the DQFCOSY spectrum. Further HMBC correlations from the carbonyl carbon (C-1) to both $\mathrm{H}_{2}-2$ and $\mathrm{H}-3$ clearly placed one of the $\mathrm{OH}$ functions at $\mathrm{C}-3\left(\delta_{\mathrm{C}} 70.5\right)$ of the dihydroxypalmitic acid. The absence of any HMBC or ROESY correlation from $\mathrm{H}-3$ to any of the sugar moieties implied that the glycosidation was not at C-3. The proton network from C-3 through C-12 was easily deduced by a careful DQF-COSY analysis. The second hydroxy group, thus the site of glycosidation, was assigned to $\mathrm{C}-12\left(\delta_{\mathrm{C}} 84.0\right)$, which exhibited a ${ }^{3} J_{\mathrm{CH}}$ correlation with the anomeric proton $\left(\mathrm{H}-1^{\prime}\right)$ of the Glu-i1. H-12 $\left(\delta_{\mathrm{H}} 3.61\right)$ showed ${ }^{1} \mathrm{H}-{ }^{1} \mathrm{H}$ correlations with $\mathrm{H}_{2}-13\left(\delta_{\mathrm{H}}\right.$ 1.67 and 1.52) $\left(\delta_{\mathrm{C}} 35.8, \mathrm{C}-13\right)$. The proton network involved two more methylene groups, $\mathrm{H}_{2}-14$ and $\mathrm{H}_{2}-15$, and terminated with the methyl group, $\mathrm{H}_{3}-16$. Overall, the carbon resonances at $\delta_{\mathrm{C}} 45.5$, $38.2,35.7$, and 35.8 were readily assigned to the carbons located at the $\beta$-positions to the oxymethine carbons on a straight aliphatic chain (C-2, C-4, C-11, C-13), while the carbon resonances observed at $\delta_{\mathrm{C}} 26.9,26.1$, and 28.7 to the carbons were located at the $\gamma$-positions (C-5, C-10, C-14). The remaining four resonances $\left(\delta_{\mathrm{C}}\right.$ 31.0-31.4 for C-6 through C-9) were consistent with carbons located between two hydroxyl groups on an aliphatic chain. ${ }^{16}$ Thus, the site of the second hydroxyl group bearing the saccharide moiety was located at $\mathrm{C}-12$; hence, the fatty acid was established as 3 ,12-dihydroxypalmitic acid.

In order to further prove the presence of 3,12-dihydroxypalmitic acid as the aglycone, 1a was subjected to acid hydrolysis, which afforded glucose and rhamnose as sugar units and 3,12-dihydroxypalmitic acid methyl ester (4). The positive ion ESIMS showed the quasi molecular ion peak at $\mathrm{m} / z 325.3[\mathrm{M}+\mathrm{Na}]^{+}$, indicating a molecular formula of $\mathrm{C}_{17} \mathrm{H}_{34} \mathrm{O}_{4}$. The ${ }^{1} \mathrm{H}$ NMR of 4 exhibited proton resonances at $\delta 3.97$ and 3.50 (both $1 \mathrm{H}, \mathrm{m}, \mathrm{H}-3$ and $\mathrm{H}-12$ ), a three proton singlet signal of a carboxymethyl at $\delta 3.67$, two methylene protons at $\delta 2.48(1 \mathrm{H}, \mathrm{dd}, J=15.0$ and $4.8 \mathrm{~Hz}, \mathrm{H}-2 \mathrm{a})$ and 2.38 $(1 \mathrm{H}, \mathrm{dd}, J=15.0$ and $8.2 \mathrm{~Hz}, \mathrm{H}-2 \mathrm{~b}$ ), and a methyl signal at $\delta 0.92$ $\left(3 \mathrm{H}, \mathrm{t}, J=6.7 \mathrm{~Hz}, \mathrm{H}_{3}-16\right)$. The ${ }^{1} \mathrm{H} \mathrm{NMR}$ data and as well as optical rotation $\left\{[\alpha]_{\mathrm{D}}{ }^{30}+1.5(c 1.4, \mathrm{MeOH})\right\}$ of 4 were in accordance with those of methyl $(+)-(3 S, 12 S)-3,12$-dihydroxyhexadecanoate $\left\{[\alpha]_{D}{ }^{20}\right.$ +1.6 ( $c$ 1.86, MeOH) \}, which was reported by Jakob \& Gerlach (1996). ${ }^{17}$ Thus, the aglycone of $\mathbf{1}$ is operculinolic acid, previously isolated from Ipomea operculata, showing an erythro configuration and $3 S, 12 S$ configuration. ${ }^{17}$ Consequently, the structure of compound 1 was established as $(+)-(3 S, 12 S)-3,12$-dihydroxypalmitic acid $12-O$ - $\{\alpha$-rhamnopyranosyl-( $1 \rightarrow 2)-O$ - $\beta$-glucopyranosyl- $(1 \rightarrow 2)$ $O$-[ $\alpha$-rhamnopyranosyl- $(1 \rightarrow 6)]\}-O$ - $\beta$-glucopyranoside, for which the trivial name cryptophilic acid A was proposed.

Compound 2 had the molecular formula $\mathrm{C}_{45} \mathrm{H}_{80} \mathrm{O}_{23}$, which was determined from the positive ion HRMALDIFTMS $\left(\mathrm{m} / \mathrm{z}[\mathrm{M}+\mathrm{Na}]^{+}\right.$
Table 2. ${ }^{13} \mathrm{C}$ NMR Data of Compounds $\mathbf{1}-\mathbf{3}(150 \mathrm{MHz})^{a}$

\begin{tabular}{|c|c|c|c|c|}
\hline carbon & DEPT 135 & 1 & 2 & 3 \\
\hline \multicolumn{5}{|c|}{ dihydroxypalmitic acid } \\
\hline 1 & $\mathrm{C}$ & 181.2 & 179.6 & 179.6 \\
\hline 2 & $\mathrm{CH}_{2}$ & 45.5 & 44.7 & 44.7 \\
\hline 3 & $\mathrm{CH}$ & 70.5 & 70.1 & 69.7 \\
\hline 4 & $\mathrm{CH}_{2}$ & 38.2 & 38.1 & 38.3 \\
\hline 5 & $\mathrm{CH}_{2}$ & 26.9 & 26.7 & 26.8 \\
\hline 6 & $\mathrm{CH}_{2}$ & $31.1^{b}$ & $31.0^{b}$ & $31.0^{l}$ \\
\hline 7 & $\mathrm{CH}_{2}$ & $31.0^{b}$ & $30.8^{b}$ & $31.1^{l}$ \\
\hline 8 & $\mathrm{CH}_{2}$ & $31.1^{b}$ & $30.9^{b}$ & $31.2^{l}$ \\
\hline 9 & $\mathrm{CH}_{2}$ & $31.4^{b}$ & $31.3^{b}$ & $31.3^{t}$ \\
\hline 10 & $\mathrm{CH}_{2}$ & 26.1 & 26.0 & 26.0 \\
\hline 11 & $\mathrm{CH}_{2}$ & 35.7 & 35.5 & 35.6 \\
\hline 12 & $\mathrm{CH}$ & 84.0 & 84.0 & 84.2 \\
\hline 13 & $\mathrm{CH}_{2}$ & 35.8 & 35.7 & 35.8 \\
\hline 14 & $\mathrm{CH}_{2}$ & 28.7 & 28.6 & 28.7 \\
\hline 15 & $\mathrm{CH}_{2}$ & 24.0 & 23.9 & 23.9 \\
\hline \multirow{2}{*}{\multicolumn{5}{|c|}{ Glu-i1-(1 $\rightarrow 12)$}} \\
\hline & & & & \\
\hline $1^{\prime}$ & $\mathrm{CH}$ & 103.6 & 103.5 & 103.7 \\
\hline $2^{\prime}$ & $\mathrm{CH}$ & 78.7 & 78.7 & 78.7 \\
\hline $3^{\prime}$ & $\mathrm{CH}$ & 79.2 & 79.3 & 79.6 \\
\hline $4^{\prime}$ & $\mathrm{CH}$ & 72.1 & 71.8 & 71.6 \\
\hline $5^{\prime}$ & $\mathrm{CH}$ & 76.7 & 76.9 & 76.7 \\
\hline $6^{\prime}$ & $\mathrm{CH}_{2}$ & 68.4 & 68.4 & 68.2 \\
\hline \multicolumn{5}{|l|}{ Glu-i2-(1" $\left.\rightarrow 2^{\prime}\right)$} \\
\hline $1^{\prime \prime}$ & $\mathrm{CH}$ & 102.2 & 101.8 & 101.9 \\
\hline $2^{\prime \prime}$ & $\mathrm{CH}$ & 79.6 & 78.4 & 78.2 \\
\hline $3^{\prime \prime}$ & $\mathrm{CH}$ & 79.4 & 78.6 & 79.3 \\
\hline 4" & $\mathrm{CH}$ & 72.7 & 72.6 & 72.7 \\
\hline $5^{\prime \prime}$ & $\mathrm{CH}$ & 78.1 & 78.1 & 78.2 \\
\hline $6^{\prime \prime}$ & $\mathrm{CH}_{2}$ & 63.7 & 63.6 & 63.7 \\
\hline \multicolumn{5}{|c|}{ Rha-t1-(1"' $\left.\rightarrow 2^{\prime \prime}\right)$} \\
\hline $1^{\prime \prime \prime}$ & $\mathrm{CH}$ & 102.3 & 101.4 & 101.4 \\
\hline $2^{\prime \prime \prime}$ & $\mathrm{CH}$ & 72.3 & 72.3 & 72.3 \\
\hline $3^{\prime \prime \prime}$ & $\mathrm{CH}$ & 72.3 & 70.2 & 70.3 \\
\hline $4^{\prime \prime \prime}$ & $\mathrm{CH}$ & 74.3 & 75.9 & 75.9 \\
\hline $5^{\prime \prime \prime}$ & $\mathrm{CH}$ & 69.6 & 67.3 & 67.4 \\
\hline \multirow{2}{*}{\multicolumn{5}{|c|}{ Rha-t2-( $\left(1^{\prime \prime \prime \prime \prime} \rightarrow 6^{\prime}\right)$}} \\
\hline & & & & \\
\hline $1^{\prime \prime \prime \prime \prime}$ & $\mathrm{CH}$ & 102.4 & 102.3 & 102.1 \\
\hline $2^{\prime \prime \prime \prime}$ & $\mathrm{CH}$ & 72.3 & 72.2 & 72.4 \\
\hline $3^{\prime \prime \prime \prime \prime}$ & $\mathrm{CH}$ & 72.5 & 72.5 & 70.5 \\
\hline $4^{\prime \prime \prime \prime \prime}$ & $\mathrm{CH}$ & 74.1 & 74.0 & 75.7 \\
\hline $5^{\prime \prime \prime \prime \prime}$ & $\mathrm{CH}$ & 69.9 & 69.8 & 67.5 \\
\hline $6^{\prime \prime \prime \prime}$ & $\mathrm{CH}_{3}$ & 18.2 & 18.2 & 18.1 \\
\hline \multicolumn{5}{|c|}{ isovaleroyl-( $\left(1 \rightarrow 4^{\prime \prime \prime}\right)$} \\
\hline $1^{\prime \prime \prime \prime \prime \prime}$ & $\mathrm{C}$ & & 174.6 & 174.6 \\
\hline $2^{\prime \prime \prime \prime \prime \prime}$ & $\mathrm{CH}_{2}$ & & 44.7 & 44.7 \\
\hline $3^{\prime \prime \prime \prime \prime \prime}$ & $\mathrm{CH}$ & & 27.0 & 27.0 \\
\hline $4^{\prime \prime \prime \prime \prime \prime}$ & $\mathrm{CH}_{3}$ & & 23.1 & 23.1 \\
\hline & $\mathrm{CH}_{3}$ & & 22.9 & 23.0 \\
\hline \multicolumn{5}{|l|}{ acetyl- $\left(1 \rightarrow 4^{\prime \prime \prime \prime}\right)$} \\
\hline $\mathrm{COCH}_{3}$ & $\mathrm{C}$ & & & 172.8 \\
\hline $\mathrm{COCH}_{3}$ & $\mathrm{CH}_{3}$ & & & 21.2 \\
\hline
\end{tabular}

${ }^{a}$ Data recorded in MeOD. Chemical shifts $(\delta)$ are in ppm. The spectra were referenced against the respective residual nondeuterated solvent peak $\left(\delta_{\mathrm{H}} 49.0\right)$. All assignments are based on HMQC and HMBC experiments ${ }^{b}$ Values are interchangable in the same column.

1011.4990; calcd for $\mathrm{C}_{45} \mathrm{H}_{80} \mathrm{O}_{23} \mathrm{Na}^{+}$requires 1011.4983). The ${ }^{1} \mathrm{H}$ and ${ }^{13} \mathrm{C}$ NMR spectra of 2 (Tables 1 and 2 ) were very similar to those of 1, except for additional signals due to a methine at $\delta 2.12$ $\left(\mathrm{H}-3^{\prime \prime \prime \prime \prime \prime}\right)$, a methylene at $\delta 2.28\left(\mathrm{H}_{2}-2^{\prime \prime \prime \prime \prime}\right)$, and two secondary methyl resonances at $\delta 0.99$ and 0.98 (each $\mathrm{d}, J=6.7 \mathrm{~Hz}, \mathrm{H}_{3}-4^{\prime \prime \prime \prime \prime \prime}$ and $\left.\mathrm{H}_{3}-5^{\prime \prime \prime \prime \prime}\right)$. The ${ }^{13} \mathrm{C}$ NMR spectrum contained the corresponding carbon resonances at $\delta 27.0\left(\mathrm{C}-3^{\prime \prime \prime \prime \prime}\right), 44.7\left(\mathrm{C}-2^{\prime \prime \prime \prime \prime}\right)$, and 23.1 and

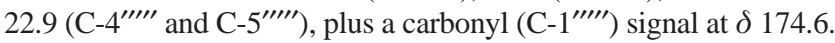
These data were in good accordance with those of isovaleric acid. ${ }^{18}$ These observations, plus a molecular mass difference of $84 \mathrm{mu}$ between the two compounds, clearly suggested that $\mathbf{2}$ was the isovaleroyl ester of $\mathbf{1}$. Alkaline hydrolysis of $\mathbf{2}$ yielded $\mathbf{1}$, verifying that $\mathbf{2}$ is the ester derivative of $\mathbf{1}$. As the $\mathrm{H}-4^{\prime \prime \prime}$ signal of the Rha-t 1 unit was deshielded by ca. $+1.6 \mathrm{ppm}\left(\delta_{\mathrm{H}} 4.94,1 \mathrm{H}, \mathrm{t}, J=10 \mathrm{~Hz}\right)$ 
compared with that of $\mathbf{1}, \mathrm{C}-4^{\prime \prime \prime}$ had to be the site of acylation. Accordingly, the C-4"' resonance was shifted downfield by ca. +1.8 $\operatorname{ppm}\left(\delta_{\mathrm{C}} 75.9\right)\left(\alpha\right.$-effect of esterification), whereas C- $3^{\prime \prime \prime}\left(\delta_{\mathrm{C}} 70.2\right)$ and $\mathrm{C}-5^{\prime \prime \prime}\left(\delta_{\mathrm{C}} 67.3\right)$ were observed at higher field $(\beta$-effect of esterification). An HMBC experiment confirmed the site of acylation, showing a ${ }^{1} \mathrm{H},{ }^{13} \mathrm{C}$-long-range correlation between the carbonyl resonance $\left(\delta_{\mathrm{C}} 174.6, \mathrm{C}-1^{\prime \prime \prime \prime \prime}\right)$ of isovaleric acid and the $\mathrm{H}-4^{\prime \prime \prime}\left(\delta_{\mathrm{H}} 4.94\right)$ of the rhamnose unit. The further long-range correlations between $\mathrm{C}-12 / \mathrm{H}-1^{\prime}, \mathrm{C}-2^{\prime} / \mathrm{H}-1^{\prime \prime}, \mathrm{C}-6^{\prime} / \mathrm{H}-1^{\prime \prime \prime \prime}$, and $\mathrm{C}-2^{\prime \prime} /$ $\mathrm{H}-1^{\prime \prime \prime}$ as well as reverse correlations between $\mathrm{C}-1^{\prime \prime} / \mathrm{H}-2^{\prime}, \mathrm{C}-1^{\prime \prime \prime \prime}$ / $\mathrm{H}-6^{\prime}, \mathrm{C}-1^{\prime \prime \prime} / \mathrm{H}-2^{\prime \prime}$, and $\mathrm{C}-1^{\prime} / \mathrm{H}-12$ supported all deductions. On the basis of these results, the structure of compound $\mathbf{2}$ was established as $(+)-(3 S, 12 S)-3,12$-dihydroxypalmitic acid $12-O-\{4-O$-isovaleroyl- $\alpha$-rhamnopyranosyl- $(1 \rightarrow 2)-O-\beta$-glucopyranosyl- $(1 \rightarrow 2)-O$ - $[\alpha-$ rhamnopyranosyl-( $(1 \rightarrow 6)]\}-O-\beta$-glucopyranoside and named cryptophilic acid B.

Compound $\mathbf{3}$ was the least polar compound on TLC, in comparison to $\mathbf{1}$ and $\mathbf{2}$. On the basis of LRESIMS (both positive and negative ion modes) and HRMALDIFTMS, its molecular formula was determined to be $\mathrm{C}_{47} \mathrm{H}_{82} \mathrm{O}_{24}(\mathrm{~m} / \mathrm{z}, 1053.5079[\mathrm{M}+$ $\mathrm{Na}]^{+}, \mathrm{C}_{47} \mathrm{H}_{82} \mathrm{O}_{24} \mathrm{Na}^{+}$requires 1053.5088). The UV, IR, and NMR spectra (Tables 1 and 2 ) of $\mathbf{3}$ were almost identical with those of 2. The only difference between $\mathbf{2}$ and $\mathbf{3}$ was the presence of an extra acetate group $\left(\mathrm{C}=\mathrm{O}: \delta_{\mathrm{C}} 172.8, \mathrm{CH}_{3}: \delta_{\mathrm{H}} 2.06 / \delta_{\mathrm{C}} 21.2\right)$ at position $4^{\prime \prime \prime \prime}$ of the upper terminal rhamnose unit (Rha-t2), which resulted in chemical shift changes in the ${ }^{1} \mathrm{H}$ NMR spectrum for $\mathrm{H}-4^{\prime \prime \prime \prime}$ from $\delta 3.37$ to 4.92 and in the ${ }^{13} \mathrm{C}$ NMR spectrum for C-4"'" from $\delta 74.0$ to 75.7. This finding was confirmed by the difference of 42 mu between compounds $\mathbf{3}$ and $\mathbf{2}$. In the HMBC experiment, a ${ }^{3} \mathrm{~J}$ correlation was observed between the acetyl carbonyl $\mathrm{COCH}_{3}$ and $\mathrm{H}-4^{\prime \prime \prime \prime}\left(\delta_{\mathrm{H}} 4.92\right)$, confirming these deductions. Finally, the structure of $\mathbf{3}$ was confirmed by alkaline hydrolysis to produce $\mathbf{1}$, verifying that $\mathbf{3}$ is the ester derivative of compound $\mathbf{1}$ and the acetyl derivative of compound $\mathbf{2}$. Thus, compound $\mathbf{3}$ is $(+)-(3 S, 12 S)-3,-$ 12-dihydroxypalmitic acid 12-O-\{4-O-isovaleroyl- $\alpha$-rhamnopyranosyl- $(1 \rightarrow 2)-O-\beta$-glucopyranosyl- $(1 \rightarrow 2)-O$-[4- $O$-acetyl- $\alpha$-rhamnopyranosyl- $(1 \rightarrow 6)]\}-O-\beta$-glucopyranoside, for which the trivial name cryptophilic acid $\mathrm{C}$ is proposed.

Iridoids and phenylethanoid glycosides are known constituents of Scrophularia species. Buddlejasaponin III has also been reported from $S$. kakudensis. ${ }^{19}$ However, $\mathbf{1 - 3}$ are new to the literature. These types of compounds have been reported only from convolvulaceous plants so far. In particular, Ipomea species (morning glory species), which have extensive traditional uses in Mexican folk medicine, are prolific producers of such compounds, which are trivially known as "resin glycosides". ${ }^{20}$ Some of the resin glycosides reported from Ipomea species include turpethinic acids A-E (I. turpethum), ${ }^{21,22}$ murucins $1-5$ and murucoidins $\mathrm{I}-\mathrm{V}$ (I. murucoides), ${ }^{23,24}$ operculinic acid, operculins (I. leptophylla), ${ }^{25}$ stoloniferins I-XII (I. stolonifera), ${ }^{26}$ scammomins I-VIII (Convolvulus scammonia), ${ }^{27,28,29}$ cuscutic acids A-D (Cuscuta chinensis), ${ }^{30}$ cuscutic acids $\mathrm{A}_{1}-\mathrm{A}_{3}$ (Cuscuta australis), ${ }^{31}$ and soldanelline A (Calystegia soldanella). ${ }^{32}$

These compounds mostly incorporate a linear tetra- or pentaglycosidic oligosaccharide unit attached to a secondary hydroxyl function of a fatty acid. The oligosaccharide moiety is often partially acylated by organic acids, such as methyl propanoic, 2-methylbutanoic, or cinnamic acids. In some cases, a second sugar is esterified with the carboxylic acid of the fatty acid to form a macrocyclic structure. The most commonly encountered fatty acids are 11hydroxypalmitic acid (jalapinolic acid), 11-hydroxytetradecanoic acid (convolvulonic acid), 3,12-dihydroxypentadecanoic acid, 3,12-dihydroxypalmitic acid, and 4,12-dihydroxypalmitic acid. Thus, the isolation of compounds $\mathbf{1} \mathbf{- 3}$, showing close structural similarity to those of resin glycosides characteristic of Convolvulaceae plants, is of taxonomic importance. This study is the first report of the isolation of resin glycosides of this type from a Scrophulariaceae plant, although they are common in Convolvulaceae plants.

\section{Experimental Section}

General Experimental Procedures. UV spectra were recorded on a Shimadzu UV-160A spectrophotometer. Optical rotations were measured on a Rudolph Autopol IV polarimeter. 1D and 2D NMR spectra were recorded on Bruker AMX (Avance) 300, 400, and 600 $\mathrm{MHz}$ spectrometers at $295 \mathrm{~K}$ using standard Bruker software and referenced against the respective residual nondeuterated solvent. ESIMS spectra were measured on a ThermoQuest Finnigan 7000 spectrometer with a spray voltage of $4 \mathrm{kV}$. HRMALDIFTMS were recorded on a Ionspec-Ultima-FTMS spectrometer. TLC analyses were carried out on silica gel $60 \mathrm{~F}_{254}$ and cellulose precoated plates $(\mathrm{O} .2 \mathrm{~mm}$; Merck, Darmstadt). A $1 \%$ vanillin $/ \mathrm{H}_{2} \mathrm{SO}_{4}$ solution was used as detection reagent for resin glycosides, and aniline phthalate was used for sugars. For medium-pressure liquid chromatographic (MPLC) separations, a Büchi B pump, a Buchi fraction collector, a Rheodyne injector, and two different sizes of Büchi columns (column dimensions $2.6 \times 46 \mathrm{~cm}$ and $1.8 \times 35 \mathrm{~cm})$ were used. Silica gel $60(0.063-0.200 \mathrm{~mm}$; Merck, Darmstadt) and Sephadex LH-20 (Fluka) were utilized for open column chromatography (CC). LiChroprep RP-18 (25-40 $\mu \mathrm{m}$, Merck) material was used for MPLC. For TLC comparison, sugar standarts D-(+)glucose (Merck, Darmstadt) and L-(+)-rhamnose (Aldrich, Steinheim) were used. Büchi RE 111 and Büchi EL 131 rotary evaporators were used throughout this study. Fractions and compounds were preserved by the lyophilization using a Virtis Freezemobile 5 lyophilizator.

Plant Material. The plant material Scrophularia cryptophila Boiss. \& Heldr. was collected from Ankara, between Beypazarı and Kıbrıscık, around Yiğerler Village in Turkey, during June 2001 and again in 2006. The voucher specimen (AAD8958) has been deposited at the Herbarium of the Department of Biology, Faculty of Science, Hacettepe University, Ankara, Turkey.

Extraction and Isolation. Air-dried and powdered aerial parts of S. cryptophila $(180 \mathrm{~g})$ were extracted three times with $\mathrm{MeOH}$ (each 2 L) at $35{ }^{\circ} \mathrm{C}$. The methanolic extracts were combined and evaporated to dryness in vacuo, yielding $34.6 \mathrm{~g}$ of crude extract. This concentrate was dissolved with $\mathrm{MeOH} / \mathrm{H}_{2} \mathrm{O}(1: 1 ; 200 \mathrm{~mL})$ and partitioned first with hexane $(3 \times 200 \mathrm{~mL})$ and then with chloroform $(3 \times 200 \mathrm{~mL})$, yielding 5.03 and $2.66 \mathrm{~g}$ extracts, respectively. The aqueous $\mathrm{MeOH}$ phase was concentrated until $100 \mathrm{~mL}$ of volume and partitioned with $n-\mathrm{BuOH}$ saturated with $\mathrm{H}_{2} \mathrm{O}(4 \times 100 \mathrm{~mL})$, yielding $7.47 \mathrm{~g}$ of $n$-butanol extract.

The $n$-BuOH extract was subjected to vacuum liquid chromatography (VLC) over reversed-phase material (LiChroprep C18), and elution with $\mathrm{H}_{2} \mathrm{O}$, followed by increasing concentrations of $\mathrm{MeOH}$ in $\mathrm{H}_{2} \mathrm{O}$ mixtures $\left(0 \rightarrow 100 \mathrm{MeOH} / \mathrm{H}_{2} \mathrm{O}\right.$ in steps of $10 \%$ of $\mathrm{MeOH}$, each $100 \mathrm{~mL}$, fraction volumes $100 \mathrm{~mL})$ as eluent, yielded nine fractions, $\mathrm{A}\left(\mathrm{H}_{2} \mathrm{O} ; 94 \mathrm{mg}\right), \mathrm{B}$ (10-20\% MeOH; $324 \mathrm{mg}$ ), C (30\% MeOH; $596 \mathrm{mg}), \mathrm{D}(40 \% \mathrm{MeOH}$; $220 \mathrm{mg}$ ), E (50\% MeOH; $494 \mathrm{mg}), \mathrm{F}(60 \% \mathrm{MeOH} ; 356 \mathrm{mg}), \mathrm{G}(80 \%$ $\mathrm{MeOH} ; 131 \mathrm{mg}), \mathrm{H}(90 \% \mathrm{MeOH} ; 227 \mathrm{mg}$ ), and I (MeOH; $2.02 \mathrm{~g})$.

Fraction A (94 mg) was applied to MPLC (LiChroprep $\mathrm{C}_{18}$, column $1.8 \times 35 \mathrm{~cm}$ ) and eluted with $\mathrm{H}_{2} \mathrm{O}$ followed by increasing concentrations of $\mathrm{MeOH}$ in $\mathrm{H}_{2} \mathrm{O}(0-100 \% \mathrm{MeOH})$ to give chlorogenic acid (14 $\mathrm{mg}$ ) and catalpol $(11 \mathrm{mg})$. Fraction B (324 mg) was applied to MPLC using similar conditions, affording aucubin $(68 \mathrm{mg})$. Fraction C (596 $\mathrm{mg})$ was applied to a silica gel $(60 \mathrm{~g})$ chromatography column with $\mathrm{CH}_{2} \mathrm{Cl}_{2} / \mathrm{MeOH} / \mathrm{H}_{2} \mathrm{O}$ (90:10:1 $\rightarrow$ 50:50:5) mixtures to yield methylcatalpol $(132 \mathrm{mg})$, tryptophan $(11 \mathrm{mg})$, aucubin $(6 \mathrm{mg})$, and harpagide (104 mg). Fraction D (220 mg) was subjected to MPLC (LiChroprep $\mathrm{C}_{18}$, column $2.6 \times 46 \mathrm{~cm}$ ) using $\mathrm{H}_{2} \mathrm{O}$ followed by increasing concentrations of $\mathrm{MeOH}$ in $\mathrm{H}_{2} \mathrm{O}(0-100 \% \mathrm{MeOH})$ to give chlorogenic acid (6 mg), methylcatalpol (14 mg), harpagide (4 mg), and aucubin (4 mg). Chromatography of fraction E (494 mg) on a silica gel column (70 g) using $\mathrm{CH}_{2} \mathrm{Cl}_{2} / \mathrm{MeOH} / \mathrm{H}_{2} \mathrm{O}$ (80:20:2 $\rightarrow$ 75:25:2.5) mixtures yielded acetylharpagide $(18 \mathrm{mg})$ and verbascoside $(27 \mathrm{mg})$. Fraction $\mathrm{F}$ (356 mg) was subjected to a silica gel $(14 \mathrm{~g})$ column using EtOAc/ $\mathrm{MeOH} / \mathrm{H}_{2} \mathrm{O}(100: 10: 1 \rightarrow 100: 10: 2)$ mixtures to afford angoroside $\mathrm{C}$ $(2 \mathrm{mg})$. Final purifications of verbascoside and angoroside $\mathrm{C}$ were performed on a Sephadex LH-20 column using $\mathrm{MeOH} / \mathrm{H}_{2} \mathrm{O}$ (4:1) mixtures. Buddlejasaponin III and compounds $\mathbf{1}-\mathbf{3}$ were rich in fractions $\mathrm{G}, \mathrm{H}$, and $\mathrm{I}$, respectively. Each fraction was separately subjected to silica gel columns using $\mathrm{CHCl}_{3} / \mathrm{MeOH} / \mathrm{H}_{2} \mathrm{O}$ with increasing polarity $(90: 10: 1 ; 85: 15: 1.5 ; 80: 20: 1 ; 70: 30: 3$; and $61: 32: 7)$, yielding crypthophilic acid A (1, $8 \mathrm{mg})$ from fraction $\mathrm{G}$, crypthophilic acid B $(2,26 \mathrm{mg})$ and buddlejasaponin III $(26 \mathrm{mg})$ from fraction $\mathrm{H}$, and finally crypthophilic acid C $(\mathbf{3}, 54 \mathrm{mg})$ from fraction $\mathrm{I}$. 
Cryptophilic Acid A (1): amorphous, colorless powder; $[\alpha]_{\mathrm{D}}{ }^{30}-57$ (c 0.1, MeOH); UV $\lambda_{\max }(\mathrm{MeOH}) \mathrm{nm}: 202$; IR $\nu_{\max }(\mathrm{KBr}) \mathrm{cm}^{-1}: 3416$ $(\mathrm{OH}), 2920(\mathrm{CH}), 1137(\mathrm{C}-\mathrm{O}-\mathrm{C}) ;{ }^{1} \mathrm{H}$ and ${ }^{13} \mathrm{C}$ NMR, see Tables 1 and 2; negative ESIMS $\mathrm{m} / \mathrm{z}[\mathrm{M}-\mathrm{H}]^{-}$903; positive ion ESIMS $\mathrm{m} / \mathrm{z}$ $[\mathrm{M}+\mathrm{H}]^{+}$927; HRMALDIFTMS $\mathrm{m} / z[\mathrm{M}+\mathrm{Na}]^{+}$927.4405; calcd for $\mathrm{C}_{40} \mathrm{H}_{72} \mathrm{O}_{22} \mathrm{Na}^{+}$requires 927.4407 .

Methylation of 1 with Diazomethane. A solution of $\mathbf{1}(20 \mathrm{mg})$ in $\mathrm{MeOH}(5 \mathrm{~mL})$ was treated with an etheral solution of diazomethane at room temperature. After removing the excess diazomethane, the mixture was evaporated to dryness under an $\mathrm{N}_{2}$ stream to yield 1a.

Cryptophilic Acid A Methyl Ester (1a): amorphous, colorless powder; ${ }^{1} \mathrm{H}$ NMR $\left(300 \mathrm{MHz}, \mathrm{CD}_{3} \mathrm{OD}\right) \delta 0.93 \mathrm{t}(3 \mathrm{H}, \mathrm{t}, J=7.0 \mathrm{~Hz}$, $\mathrm{H}_{3}-16$ ), 1.24 and 1.25 (each $3 \mathrm{H}, \mathrm{d}, J=6.3 \mathrm{~Hz}, \mathrm{H}_{3}-6^{\prime \prime \prime}$ and $\mathrm{H}_{3}-6^{\prime \prime \prime \prime}$ ), 1.33 (10H, br s, $\left.\mathrm{H}_{2}-6-\mathrm{H}_{2}-9\right), 1.34-1.70\left(6 \mathrm{H}, \mathrm{H}_{2}-4-\mathrm{H}_{2}-5, \mathrm{H}_{2}-10, \mathrm{H}_{2-}\right.$ $\left.11, \mathrm{H}_{2}-13-\mathrm{H}_{2}-15\right), 2.40(1 \mathrm{H}, \mathrm{dd}, J=15.0,4.8 \mathrm{~Hz}, \mathrm{H}-2 \mathrm{~b}), 2.29(1 \mathrm{H}$, dd, $J=15.0,8.3 \mathrm{~Hz}, \mathrm{H}-2 \mathrm{a}), 3.11-4.13\left(22 \mathrm{H}, \mathrm{H}-3, \mathrm{H}-12, \mathrm{H}-2^{\prime}-\mathrm{H}-6^{\prime}\right.$, $\left.\mathrm{H}-2^{\prime \prime}-\mathrm{H}-6^{\prime \prime}, \mathrm{H}-2^{\prime \prime \prime}-\mathrm{H}-5^{\prime \prime \prime}, \mathrm{H}-2^{\prime \prime \prime \prime}-\mathrm{H}-5^{\prime \prime \prime \prime}\right), 3.67$ (3H, s, $\left.-\mathrm{COOCH}_{3}\right)$, $4.32\left(1 \mathrm{H}, \mathrm{d}, J=7.6 \mathrm{~Hz}, \mathrm{H}-1^{\prime}\right), 4.70\left(1 \mathrm{H}, \mathrm{d}, J=1.7 \mathrm{~Hz}, \mathrm{H}-1^{\prime \prime \prime \prime}\right), 4.90$ $\left(1 \mathrm{H}, \mathrm{d}, J=7.8 \mathrm{~Hz}, \mathrm{H}-1^{\prime \prime}\right), 5.21\left(1 \mathrm{H}, \mathrm{d}, J=1.7 \mathrm{~Hz}, \mathrm{H}-1^{\prime \prime \prime}\right)$; negative ESIMS $m / z[\mathrm{M}-\mathrm{H}]^{-}$917.4; positive ion ESIMS $m / z[\mathrm{M}+\mathrm{Na}]^{+} 941.5$ (calcd for $\mathrm{C}_{41} \mathrm{H}_{74} \mathrm{O}_{22} \mathrm{Na}^{+}$).

Acid Hydrolysis of 1a. Compound 1a (15 mg) was dissolved in 3 $\mathrm{mL}$ of $5 \% \mathrm{HCl}$ solution, heated at $100{ }^{\circ} \mathrm{C}$ for $2 \mathrm{~h}$, and then cooled. The reaction mixture was diluted with $\mathrm{H}_{2} \mathrm{O}(3 \mathrm{~mL})$ and extracted with $\mathrm{CH}_{2} \mathrm{Cl}_{2}(3 \times 5 \mathrm{~mL})$. The combined $\mathrm{CH}_{2} \mathrm{Cl}_{2}$ extract was evaporated to dryness, yielding $4 \mathrm{mg}$ of $\mathbf{4}$. The water phase was neutralized by passing it through Dowex resin $(\mathrm{Cl}$ form). The filtrate was evaporated to dryness, dissolved in pyridine, and subjected to TLC analysis (cellulose plate, EtOAc/pyridine/AcOH $\left.-\mathrm{H}_{2} \mathrm{O}, 32: 32: 7: 21\right)$. Rhamnose and glucose were detected as sugar constituents on TLC by comparison with the standard compounds.

(+)-(3S,12S)-3,12-Dihydroxypalmitic Acid Methyl Ester (4): $[\alpha]_{\mathrm{D}}^{30}+1.5(c 0.14, \mathrm{MeOH}) ;{ }^{1} \mathrm{H}$ NMR $\left(300 \mathrm{MHz}, \mathrm{CDCl}_{3}\right) \delta 3.97(1 \mathrm{H}$, $\mathrm{m}, \mathrm{H}-3), 3.67\left(3 \mathrm{H}, \mathrm{s}, \mathrm{COOCH}_{3}\right), 3.50(1 \mathrm{H}, \mathrm{m}, \mathrm{H}-12), 2.48(1 \mathrm{H}, \mathrm{dd}, J$ $=15.0$ and $4.8 \mathrm{~Hz}, \mathrm{H}-2 \mathrm{a}), 2.38(1 \mathrm{H}, \mathrm{dd}, J=15.0$ and $8.2 \mathrm{~Hz}, \mathrm{H}-2 \mathrm{~b})$, $1.70-1.34$ and 1.32 (totally $22 \mathrm{H}$, all methylene protons) and $0.92(3 \mathrm{H}$, $\left.\mathrm{t}, J=6.7 \mathrm{~Hz}, \mathrm{H}_{3}-16\right)$; positive ion ESIMS $m / z, 325.3\left[\mathrm{M}+\mathrm{Na}^{+}{ }^{+}\right.$calcd for $\mathrm{C}_{17} \mathrm{H}_{34} \mathrm{O}_{4} \mathrm{Na}$ ).

Cryptophilic Acid B (2): amorphous, colorless powder; $[\alpha]_{\mathrm{D}}^{30}-38$ (c $0.1, \mathrm{MeOH})$; UV $\lambda_{\max }(\mathrm{MeOH}) \mathrm{nm}: 201$; IR $\nu_{\max }(\mathrm{KBr}) \mathrm{cm}^{-1}: 3415$ $(\mathrm{OH}), 2930(\mathrm{CH}), 1725$ (ester $\mathrm{C}=\mathrm{O}) ;{ }^{1} \mathrm{H}$ and ${ }^{13} \mathrm{C}$ NMR, see Tables 1 and 2; negative ESIMS $\mathrm{m} / \mathrm{z}$ [M $-\mathrm{H}]^{-}$987; positive ion ESIMS $\mathrm{m} / \mathrm{z}$

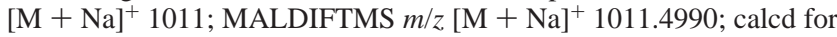
$\mathrm{C}_{45} \mathrm{H}_{80} \mathrm{O}_{23} \mathrm{Na}^{+}$requires 1011.4983 .

Cryptophilic Acid C (3): amorphous, colorless powder; $[\alpha]_{\mathrm{D}}{ }^{30}-37$ (c 0.1, MeOH); UV $\lambda_{\max }(\mathrm{MeOH}) \mathrm{nm}: 202$; IR $v_{\max }(\mathrm{KBr}) \mathrm{cm}^{-1}: 3425$ $(\mathrm{OH}), 2932(\mathrm{CH}), 1733$ (ester $\mathrm{C}=\mathrm{O}) ;{ }^{1} \mathrm{H}$ and ${ }^{13} \mathrm{C}$ NMR, see Tables 1 and 2; negative ESIMS $\mathrm{m} / z[\mathrm{M}-\mathrm{H}]^{-} 1029$; positive ion ESIMS $\mathrm{m} / \mathrm{z}$ $[\mathrm{M}+\mathrm{Na}]^{+} 1053$; MALDIFTMS $\mathrm{m} / z[\mathrm{M}+\mathrm{Na}]^{+}$1053.5079; calcd for $\mathrm{C}_{47} \mathrm{H}_{82} \mathrm{O}_{24} \mathrm{Na}^{+}$requires 1053.5088 .

Alkaline Hydrolysis of $\mathbf{2}$ and 3. The samples of $\mathbf{2}$ and $\mathbf{3}$ (each 5 $\mathrm{mg}$ ) were dissolved in $5 \% \mathrm{KOH}$ in $\mathrm{H}_{2} \mathrm{O}(2 \mathrm{~mL})$ separately and heated under reflux for $2 \mathrm{~h}$ at $80^{\circ} \mathrm{C}$. After cooling, the solutions were diluted with $\mathrm{H}_{2} \mathrm{O}$ and partitioned with diethyl ether $(3 \times 5 \mathrm{~mL})$. The $\mathrm{H}_{2} \mathrm{O}$ phases were then acidified with $1 \% \mathrm{H}_{2} \mathrm{SO}_{4}$. The reaction mixtures were separately placed on small C18 flash columns (LiChroprep C-18; $2 \times$ $3 \mathrm{~cm}$ ), which were first eluted with $\mathrm{H}_{2} \mathrm{O}$ (each $20 \mathrm{~mL}$ ), followed by excess $\mathrm{MeOH}$. The $\mathrm{MeOH}$ fractions were concentrated under reduced pressure to yield crypthophilic acid A (1, each ca. $3 \mathrm{mg}$ ). The identities of the alkaline hydrolysates derived from $\mathbf{2}$ and $\mathbf{3}$ were compared with 1 on TLC, using $\mathrm{CH}_{2} \mathrm{Cl}_{2} / \mathrm{MeOH} / \mathrm{H}_{2} \mathrm{O}$ mixtures (70:30:3 and 61:32:7) as solvents.

\section{References and Notes}

(1) Scrophularia, L.; Lall, S. S.; Mill, R. R. In Flora of Turkey and the East Aegean Islands, Davis, P. H., Ed.; Edinburgh University Press: Edinburgh, 1978; Vol. 6, pp 603-647.

(2) Çalış, I.; Gross, G.-A.; Sticher, O. Phytochemistry 1987, 26, 20572061

(3) Çalış, İ; Gross, G.-A.; Sticher, O. Phytochemistry 1988, 27, 14651468

(4) Çalış, I.; Gross, G.-A.; Winkler, T.; Sticher, O. Planta Med. 1988, $54,168-170$.

(5) Çalış, İ; Özipek, M.; Doga. Turk. J. Pharm. 1992, 2, 25-33.

(6) Çalış, I.; Zor, M.; Başaran, A.; Sticher, O. Helv. Chim. Acta 1993, 76, 1352.

(7) Çalış, I.; Zor, M.; Başaran, A.; Sticher, O. J. Nat. Prod. 1993, 56, 606-609.

(8) Tasdemir, D.; Güner, N. D.; Perozzo, R.; Brun, R.; Dönmez, A. A.; Çalış, I.; Rüedi, P. Phytochemistry 2005, 66, 355-362

(9) Chaudhuri, R. K.; Sticher, O. Helv. Chim. Acta 1981, 64, 3-15.

(10) Bianco, A.; Passacantilli, P.; Polidori, G. Gazz. Chim. Ital. 1983, 113, 829-834.

(11) Çalış, İ.; Basaran, A. A.; Saracoglu, I.; Sticher, O. Phytochemistry 1992, 31, 167-169.

(12) Pauli, G. F.; Kuczkowiak, U.; Nahrstedt, A. Magn. Reson. Chem. 1999, 37, 827-836.

(13) Gross, G.-A. Ph.D. Thesis (Diss. ETH Nr. 7800), Swiss Federal Institute of Technology Zurich, 1985.

(14) Sticher, O.; Lahloub, M. F. Planta Med. 1982, 46, 145-148

(15) Yamamoto, A.; Miyase, T.; Ueno, A.; Maeda, T. Chem. Pharm. Bull. 1991, 39, 2764-2766.

(16) Pretsch, E.; Seibl, J.; Simon, W.; Clerc, T. Tabellen zur Strukturaufklärung Organischer Verbindungen; Springer-Verlag: Berlin, 1981.

(17) Jakob, B.; Gerlach, H. Liebigs Ann. 1996, 2123-2129.

(18) Handjieva, N.; Baranovska, I.; Mikhova, B.; Popov, S. Phytochemistry 1988, 27, 3175-3179.

(19) Yamamoto, A.; Miyase, T.; Ueno, A.; Maeda, T. Chem. Pharm. Bull. 1993, 41, 1780-1783.

(20) Diaz, J. L. Usos de las Plantas Medicinales de Mexico; Monograficas Cientifica II; INEPLAM: Mexico, 1976; p 329.

(21) Wagner, H.; Wenzel, G.; Chari, V. M. Planta Med. 1978, 33, 144151.

(22) Wagner, H.; Schwarting, G.; Varljen, J.; Bauer, R.; Hamdard, M. E.; El-Faer, M. Z.; Beal, J. Planta Med. 1983, 49, 154-157.

(23) León, I.; Enríquez, R. G.; Nieto, D. A.; Alonso, D.; Reynolds, W. F., Aranda, E.; Villa, J. J. Nat. Prod. 2005, 68, 1141-1146.

(24) Chérigo, L.; Pereda-Miranda, R. J. Nat. Prod. 2006, 69, 595-599.

(25) Barnes, C. C.; Smalley, M. K.; Manfredi, K. P.; Kindscher, K.; Loring, H.; Sheeley, D. M. J. Nat. Prod. 2003, 66, 1457-1462.

(26) Noda, N.; Takahashi, N.; Miyahara, K.; Yang, C.-R. Phytochemistry 1998, 48, 837-841.

(27) Noda, N.; Kogetsu, H.; Kawasaki, T.; Miyahara, K. Phytochemistry 1990, 29, 3565-3569.

(28) Kogetsu, H.; Noda, N.; Kawasaki, T.; Miyahara, K. Phytochemistry 1991, 30, 957-963.

(29) Noda, N.; Kogetsu, H.; Kawasaki, T.; Miyahara, T. Phytochemistry 1992, 31, 2761-2766.

(30) Du, X.-M.; Kohinata, K.; Kawasaki, T.; Guo, Y.-T.; Miyahara, K. Phytochemistry 1998, 48, 843-850.

(31) Du, X.-M.; Sun, N.-Y.; Nishi, M.; Kawasaki, T.; Guo, Y.-T.; Miyahara, K. J. Nat. Prod. 1999, 62, 722-725.

(32) Gaspar, E. M. M. Tetrahedron Lett. 1999, 6861-6864.

NP060511K 